Portland State University

PDXScholar

Engineering and Technology Management

Faculty Publications and Presentations

$1-5-2017$

\title{
Survey of Value Assessment Programs within Transportation Construction Projects in U.S
}

\author{
Rafaa Khalifa \\ Portland State University \\ Robert Stewart \\ Value Management Strategies, Inc.
}

Follow this and additional works at: https://pdxscholar.library.pdx.edu/etm_fac

Part of the Engineering Commons

Let us know how access to this document benefits you.

\section{Citation Details}

R. Khalifa and R. Stewart, "Survey of value assessment programs within transportation construction projects in U.S," 2016 Portland International Conference on Management of Engineering and Technology (PICMET), Honolulu, HI, 2016, pp. 2102-2118.

This Article is brought to you for free and open access. It has been accepted for inclusion in Engineering and Technology Management Faculty Publications and Presentations by an authorized administrator of PDXScholar. Please contact us if we can make this document more accessible: pdxscholar@pdx.edu. 


\title{
Survey of Value Assessment Programs within Transportation Construction Projects in U.S
}

\author{
Rafaa Khalifa ${ }^{1}$, Robert Stewart ${ }^{2}$ \\ ${ }^{1}$ Department of Engineering and Technology Management, Portland State University, Portland, Oregon - USA \\ ${ }^{2}$ Value Management Strategies, Inc., Portland, Oregon - USA
}

\begin{abstract}
In order to deliver transportation project on time and within budget, project planners and decision makers need to understand the desirable outcomes of projects or programs to make intelligent decisions. In addition, they also need effective tools and techniques to guide those decisions. In development of a guide that identifies available tools and techniques to foster useable and improved practices for key stakeholders of transportation projects, this paper as a preliminary study assessed current utilization of project delivery value improvement programs such as value engineering (VE), risk analysis/management (RA/RM) and constructability reviews (CR) for transportation projects. To determine whether states have adapted any of these programs or other innovative project delivery techniques, state DOT initiatives were studied through a review of past research and reports. Also, the collection of documents relevant to DOT practices that have been used as a literature review to identify and design the survey questions. Value Management Strategic (VMS), academic advisors at Portland State University (PSU), and project delivery experts were consulted to advice and validate the survey questions before and after the distribution stage. Then, three surveys of VE, RA, and CR were carried out with state DOT staff. Finally, the survey results were discussed in-depth in this paper to address the main issues of these programs and the level of its conducting within the project delivery processes related to transportation construction projects.
\end{abstract}

\section{INTRODUCTION}

In recent years, there has been increasing concern within public transportation agencies regarding construction projects. Projects are delayed and project costs increase which adversely impact the economy and public image.

The demand to deliver transportation projects in less time with limited budgets has driven the department of transportation (DOTs) in each state to research, develop and adapt innovation tools, methods, processes, or programs for its construction projects. Due to, the high level of risk and uncertainty in most transportation projects, especially in the cities and towns that have a large density of pollution, the selection of an appropriate delivery method has been more difficult and involves complex decision making. Furthermore, some research has been conducted on the performance of project delivery methods in transportation and proved that there is a lack of comprehensive comparative approaches combined with adequate orientation into the future to provide a sufficient basis for strategic decisions.

The exploration of alternative project delivery methods and programs for transportation and other infrastructure projects is the result of the insistent need to rapidly improve project delivery strategies. The Transportation Research Board (TRB) of the National Academies, the National
Research Council (NRC), the Federal Highway Administration (FHWA), the American Association of State Highway and Transportation Officials (AASHTO), the National Cooperative Highway Research Program (NCHRP), and States Department of Transportation are actively researching best practices to allocate risk more effectively while achieving high performance and maximum value for transportation projects. Some DOTs adapt and use the most common project delivery tools in the construction industry such as design-build (DB), construction manager/general contractor (CMGC), construction manager at-risk (CMR), and at times design-bid-build best-value (DBB-BV) contracts. These tools lead to take advantage of the design and construction industry's ideas for alternative design and construction solutions to highway projects. [1] Stated that the FHWA's "every day counts" program is designed to identify and deploy innovation aimed to reduce the time of project delivery with more concerning of increasing the safety and protecting the environment in new or developing projects.

Other programs and practices have been developed and introduced to help the transportation agencies decision makers and the construction project's members to improve the project delivery process and outcome. These improvements include factors such as cost, performance, time, risk, reliability, flexibility, sustainability, competitiveness, etc. This paper aims to survey current practices within public transportation agencies regarding their currently perform Value Engineering (VE), Risk Analysis (RA), and Constructability review (CR) activities; how they are interrelated; and to what extent they are integrated and support each other. The survey will lead to investigate the effectiveness of these programs of measuring the success of outcomes relating to the delivery of transportation projects.

\section{LITERATURE REVIEW}

Project delivery methods define the relationships, roles, and responsibilities of project team members and sequences of activities required to complete a project [2]. Each projectdelivery method can save time and money while delivering comparable quality to projects. However, many issues arise in the early stages of a project involving construction. Often the most challenging task, when large cost and complexity of construction is involved [3]. Anderson [4] evaluated the potential for alternative construction methods to accelerate project completion and what the impact would be. Tran [5] described that the selection of an appropriate delivery method is a complex decision due in large part to the risk and uncertainty at the time of the decision. The same authors 
indicated that the growing use of alternative delivery methods has led researchers and practitioners to search for structured approaches to choose project-delivery methods. The TRB, NRC, FHWA, AASHTO, and the individual states participating in the NCHRP have started in partnering cooperating with universities and private consulting companies to develop other innovative techniques, tools, applications or processes that reflect their own projects' circumstances and requirements. Some of the research focuses on current practices within public transportation agencies regarding how they currently perform VE, RA and $\mathrm{CR}$ activities and to what level they are integrated and support each other; the effectiveness of these programs; and an evaluation of current methods of measuring the success of outcomes (i.e., cost savings, performance benefits, risk reduction, accelerated delivery, etc.). In the same subject, to understand the impact of these techniques on project delivery, Terry [6] indicated that the VE can help the owner and design-build team ensure the project satisfies need and purpose in an effective and efficient manner, resolve issues and gain early consensus for project direction, and help the design-build team function even more effectively. VE is a function-oriented technique that has proven to be an effective management tool for achieving improved design, construction, and cost-effectiveness in various transportation program elements [7]. The Federal-Aid Highway Program emphases in its Value Engineering report that over many years, VE has evolved into a management tool that can be used alone or with other management techniques to improve operations, project quality and reduce project costs.

DOTs have realized substantial savings by using value engineering, these savings occur by restructuring operations and implementing cost saving recommendations [8]. FHWA defines $\mathrm{VE}$ as a systematic process of project review and analysis during the concept and design phases by a multidisciplinary team of individuals involved in the project conducted to provide recommendations. The outcome of a VE study usually covers the recommendations of providing the required functions safely, reliably, efficiently, and at the lowest overall cost. Also, it cover improving the value and quality of the project, and reducing the time to complete the project [9]. NCHRP Synthesis 352 report refers to VE as a process that is more effective and influential on the performance, quality, and cost of a project when performed relatively early in the development of the project [10]. Furthermore, [10] VE can effectively be integrated with or into other technical management improvement approaches. In order to investigate the relation between the VE and CR programs, David [11] indicated that $\mathrm{CR}$ is not VE, there is significant differences between both of them such as timing and scope of service. Constructability Review is most beneficial when performed prior to establishment of defined scope, during early planning and design phases. David Ruby stressed that the VE is usually performed during the final stages of design development which limits the opportunity to make a significant impact on the project's cost or schedule
[11]. The Idaho Department of Transportation's Constructability Review Guidelines states that CR is a systematic process that ensures the feasibility of project construction. The $\mathrm{CR}$ process starts at the beginning of the project and continues throughout project development [12]. Several constructability reviews are incorporated into the project planning and development. Indiana Department of Transportation (INDOT) has endorsed constructability reviews to improve the total quality of construction bid package. The department works to ensure construction knowledge and experience in planning and design is effectively applied to achieve the project objectives [13]. The Idaho Department of Transportation incorporates constructability reviews into the design processes [12]. Project risk is an uncertain event that, if it occurs, has a negative or positive impact on a project's objectives, cost, schedule, or quality [14]. [15] Project Management is described as a customizable effort corresponding with the size and complexity of the project under consideration. The Risk Management Guideline of New Jersey Department of Transportation added that in addition to size and complexity, other factors to be considered for the level of efforts may include cost, location, delivery timeframe, construction time frame, and so forth [15]. DOT executive leaders are encouraged to embrace risk management as part of their overall program delivery processes, and use the guidance in herein to examine their own programs and processes for risk management opportunities, as part of improving overall service to the public [16]. Regarding the integration between these programs (VE, RA, CR) the NCHRP SYNTHESIS 455 emphasized that integration can be achieved in a number of ways [17]. To support the statement, [17] [18] addresse the VE and CR need to be integrated with Risk Analysis (RA) and Risk Management (RM) process framework and applied during the project development phases.

\section{RESEARCH METHODOLOGY}

\section{A. Purpose:}

This paper presents the survey results and discussion performed for VE, RA, and CR programs. The survey was distributed online to target professionals (project managers, project engineers, and project coordinators) who are currently working for DOTs and other transportation organizations throughout the U.S. These professionals have experience in the construction industry mostly in transportation projects. The goal of the survey to answer the prepared questions that designed for the three programs (VE, RA, and CR) as project delivery initiatives. In addition, the survey results will identify a clear picture emerged regarding the integrating and improving of these programs as best practices of project delivery being applied in transportation infrastructure projects in U.S. 


\section{B. Survey strategy and process:}

The survey questions were developed based on the research objective that targeted three best practices of project delivery related the transportation construction projects. The authors started with a literature review of different academic papers and industry reports as a first step. The literature review focused on VE, RA, and CR programs in project delivery. Value Management Strategic (VMS), academic advisors at Portland State University (PSU), and project delivery experts were consulted to advice and validate the survey questions before and after the distribution stage. Figure (1) shows how the survey was outlined based on seven stages as follows:

- Identify the research objective

- Literature review
- Development of the survey questionnaire (VE, RA, \& CR)

- Testing and validation

- Survey distribution

- Analysis of the responses

- Interpretation of the results.

The questionnaire was sent based on a contacts list from AASHTO to transportation public agencies. The contact list was selected to ensure that a knowledgeable group of professionals would respond to the questionnaire. We chose the DOTs as a main target to collect most of the survey information.

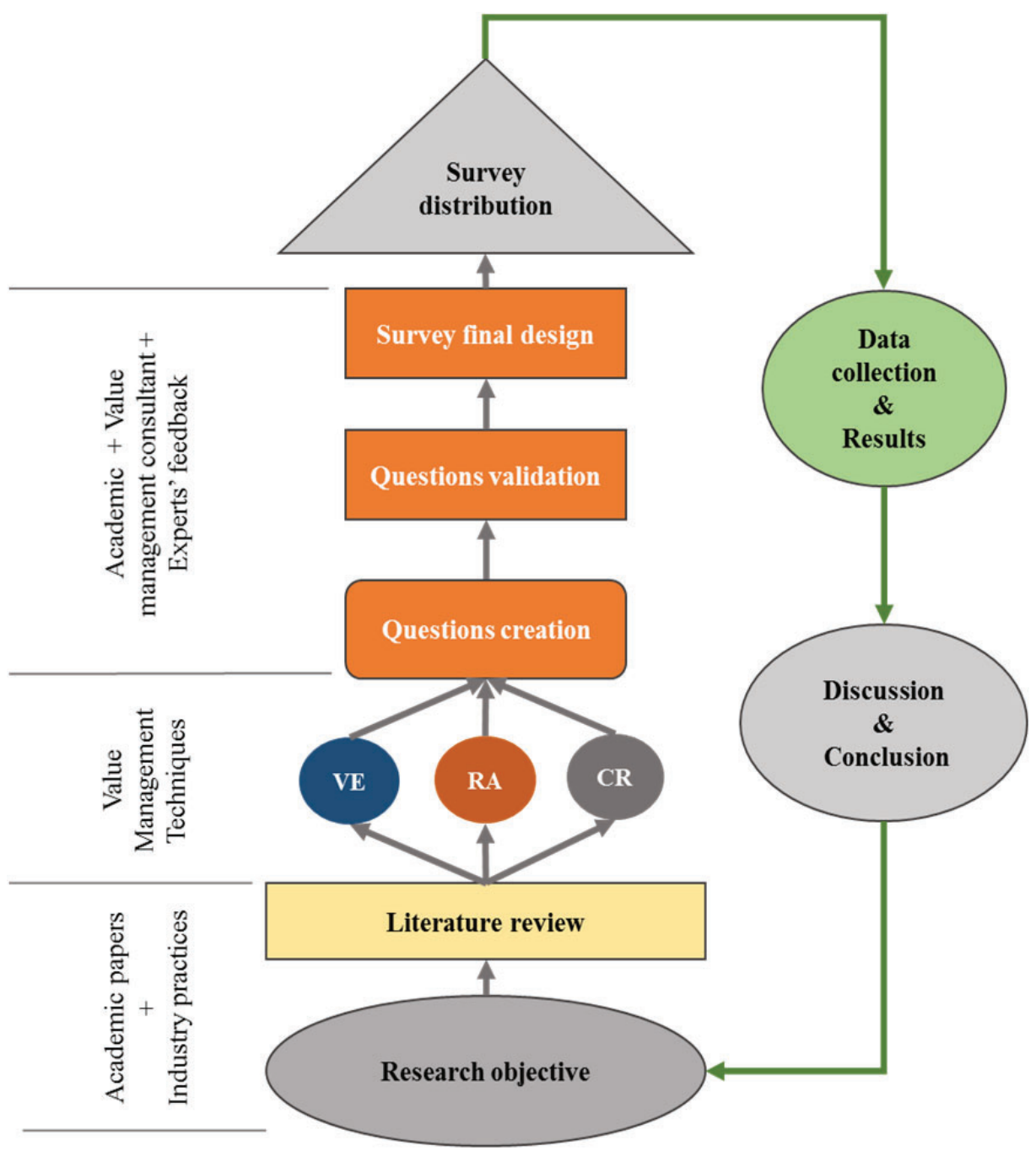

Figure (1) the survey framework 


\section{Proceedings of PICMET '16: Technology Management for Social Innovation}

\section{DATA COLLECTION:}

The list of respondents was developed to cover individuals in various state DOTs as well as state the Federal Highway Administration (FHWA) liaisons and individuals from other transportation agencies. In July $1^{\text {st }} 2015$ eightyfive emails sent to DOT coordinators to collect information from a knowledgeable group of professionals that would likely respond to the questionnaire. In the first round 20 out of 85 emails replied positively with the contact list of VE, RA, and CR professionals, each list included from 4 to 6 contacts. In August $1^{\text {st }} 2015$ a remainder email sent to who did not reply in the first round, the rate of responses had increased by $53 \%$ and the actual responses to our request by providing the contact list were $39 \%$ from a total of 85 email requests.

In August $13^{\text {th }}$ 2015, three formal online surveys were distributed to VE, RA, and CR professionals. A total of 85 survey requests were sent out for the VE, 45 for the RA, and 31 for the CR. These surveys were conducted covering VE, $\mathrm{RA}$, and CR questionnaires that were sent to over 156 public officials. The number of survey which is distributed, responses, and completed in each area are summarized in Table 1. Also, the progress of responses who have completed the survey were $40 \%, 42 \%$, and $41 \%$ in VE, RA, and CR respectively.

TABLE (1) THE SURVEY STATUS

\begin{tabular}{|c|c|c|c|}
\hline Program & \# of Distributed & \# of Responses & \# of Completed \\
\hline VE & 85 & 38 & 34 \\
\hline RA & 31 & 14 & 13 \\
\hline CR & 41 & 19 & 17 \\
\hline
\end{tabular}

\section{RESULTS}

\section{A. Policy and Guidance:}

As shown in the Figure 2, the majority of respondents $(82 \%)$ stated that their transportation agencies have a formal Value Engineering policy and the most recently updated policy was in June, 2015. For the risk analysis/assessment activity, approximately $70 \%$ of responding transportation agencies indicated that they had a formal Risk Analysis and/or Risk Management (RA/RM) policy. Those agencies that had a formal policy indicate that it was most commonly recently created between 2010 and now. Respondents of the Constructability Review survey indicated that more transportation organizations did not have a formal CR policy $(59 \%)$ than those that did have a formal policy $(41 \%)$. For those organizations that did have a formal CR policy most were recently updated between 2010 and 2012. Just on agency had updated the policy in March 2015.

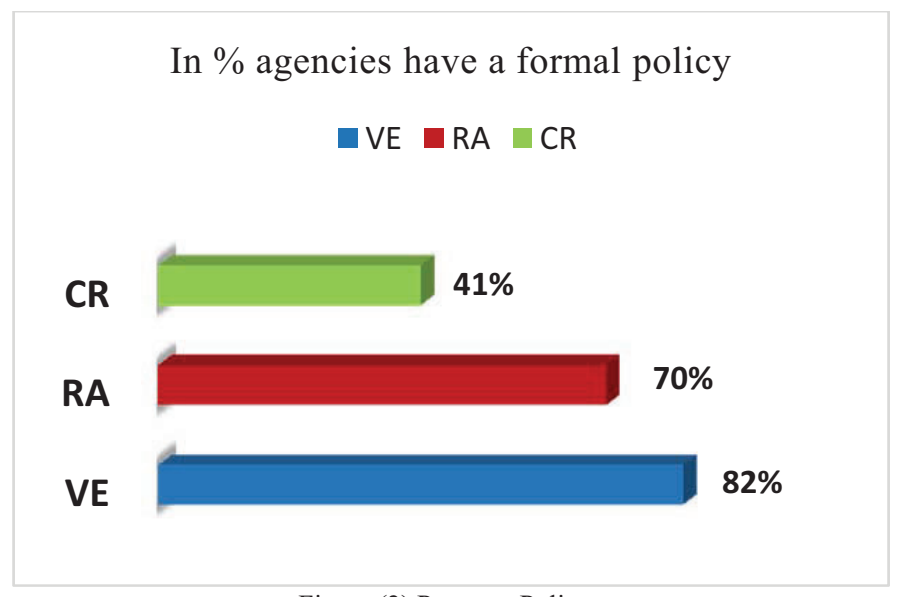

Figure (2) Program Policy

\section{B. Thresholds:}

Figure 3 shows that there are different $(\$)$ dollar threshold for performing VE, RA, and $\mathrm{CR}$ in transportation projects among DOTs. The majority of respondents indicated that the project cost from $\$ 40$ to $\$ 50$ million is required to the $\mathrm{VE}$ program. Approximately $70 \%$ of responding transportation agencies indicated that they did not have an established dollar threshold for the performing of risk analysis or risk management activities; however, the $30 \%$ of agencies that did have a threshold indicated that it was commonly $\$ 10$ million or less or that risk management is mandated on all projects regardless of dollar size. In the constructability review program, $82 \%$ of transportation organizations indicated that they do not have an established dollar threshold for conducting a constructability review. Those organizations that do have a formal constructability review policy indicated that criteria were that generally all projects must undergo a review. Other agencies indicated that costs in exceedance of $\$ 500 \mathrm{~K}$ was a threshold that triggers the need for a constructability review.

\section{Program Facilitation:}

The survey results indicated in Figure 4 that approximately $59 \%$ of all VE studies performed during the period were facilitated by consultants while $41 \%$ were performed in-house. About $70 \%$ of responding organizations internally conduct RA/RM activities. Another 23\% of respondents rely on internal staff and external consultants and only $7 \%$ of organizations rely solely on external consultants. In the CR survey, respondents indicated that about $87 \%$ of transportation organizations that do conduct constructability review they were internal facilitated. The remaining $13 \%$ indicated that constructability reviews are both internally and externally facilitated. 


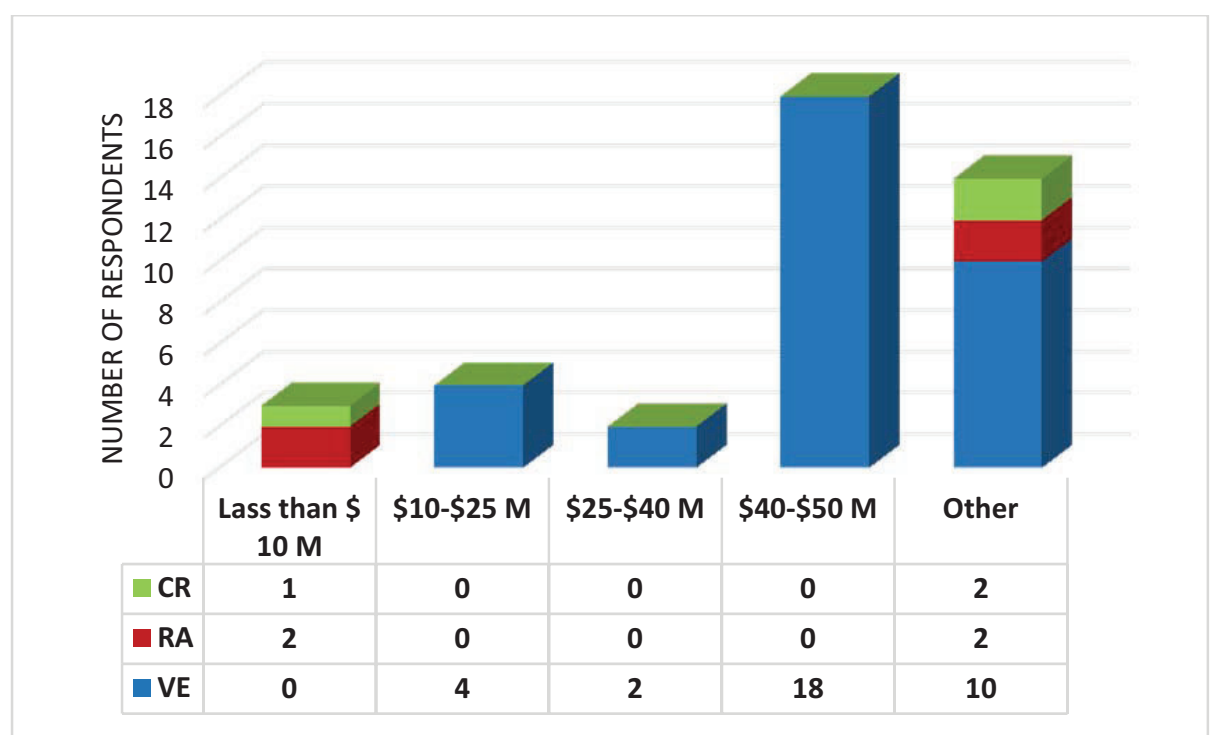

Figure (3) a dollar threshold for performing programs

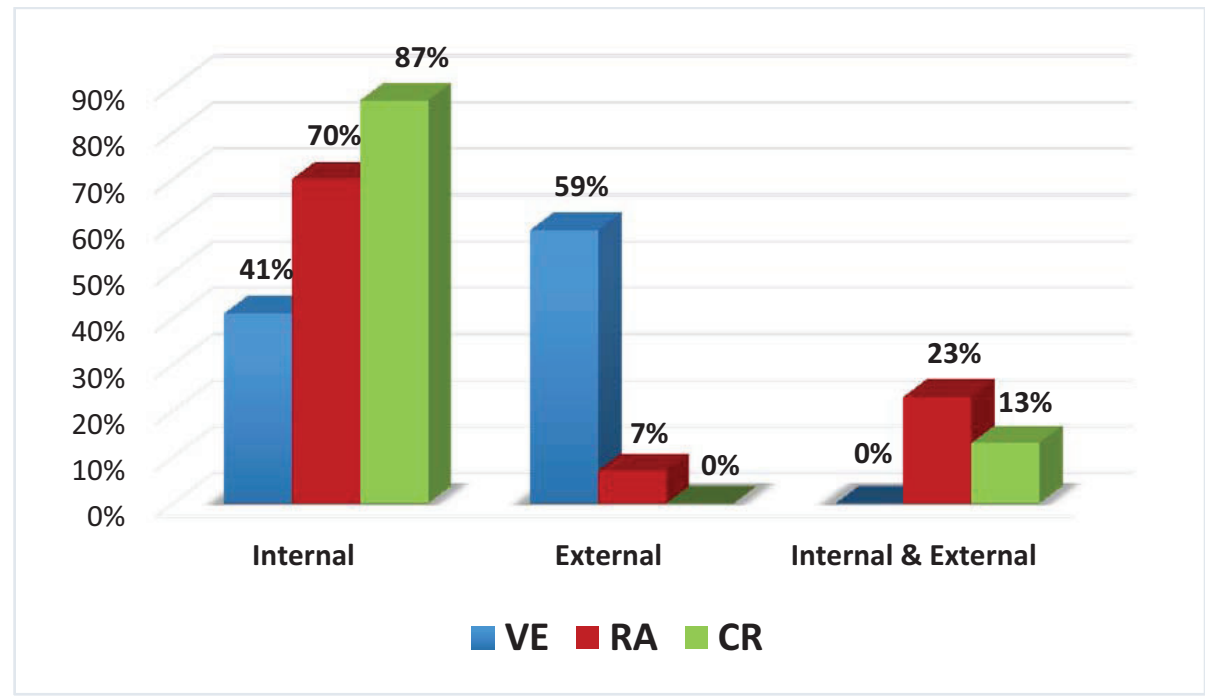

Figure (4) the $\%$ of each program facilitation

\section{Criteria:}

The respondents were asked about other criteria for selecting projects to perform Value Engineering (VE), Risk Analysis (RA), or constructability review (CR) study on transportation projects in their agencies or organization. Table .2 shows that most agencies implement other parameters that use to perform the required studies for each project selection individually. This is in line with the survey results, as the most-use in the three programs (VE, RA, and CR) of transportation agencies are Project Phasing Challenges, Staging Complexity, and Utility Challenges.

TABLE (2) NUMBER OF RESPONDENTS REGARDING THE CRITERIA TO PERFORM VE, RA, AND CR STUDIES

\begin{tabular}{|c|c|c|c|}
\hline Criteria & VE & $\mathbf{R A}$ & CR \\
\hline Project Phasing Challenges & 20 & 5 & 13 \\
\hline Staging Complexity & 17 & 6 & 13 \\
\hline Right-of-Way Issues & 13 & 7 & 5 \\
\hline Environmental Challenges & 15 & 6 & 6 \\
\hline Utility Challenges & 15 & 7 & 10 \\
\hline New/Advanced Technical Challenges & 21 & 5 & 5 \\
\hline External agency/stakeholder involvement & 12 & 5 & 4 \\
\hline Building consensus with multiple stakeholders & 13 & 5 & 3 \\
\hline Others & 0 & 6 & 5 \\
\hline
\end{tabular}




\section{E. Timing:}

The respondents were asked about the timing of performing of each program during the project phases. As shown in the Figure (5) below, the majority of respondents $(60 \%)$ indicated that they perform VE studies during preliminary design. Nearly half (45\%) said that VE studies are being conducted during final engineering and about one quarter $(28 \%)$ during project planning and/or feasibility. In the Risk Analysis survey, all respondents indicated that risk analysis is conducted during preliminary design. The usage declines the further along in project delivery agencies are as $75 \%$ of respondents use risk analysis in planning stage, $67 \%$ use risk analysis during final design, and $42 \%$ use risk analysis during construction. In the same subject the Constructability Review survey shows that the most respondents about $93 \%$ indicated that most constructability review are conducted on final design, while $7 \%$ of respondents indicated that the constructability review are conducted during the planning and other $7 \%$ during the construction stage. $53 \%$ of survey respondents indicated that the constructability review are conducted during environment studies or preliminary design.

\section{F. Program Integration:}

The survey results indicate different levels of performing each activity (VE, RA, or CR) in combination with each other within transportation organizations and agencies. As shown in the Figure (6) below, $8 \%$ of respondents indicated that risk analysis was always performed in conjunction with Value Engineering. Another $42 \%$ of respondents indicated that the Risk Analysis is sometimes performed with Value Engineering or that it is determined on a case-by-case basis. About $27 \%$ of the time the Constructability Reviews are performed with the Value Engineering, other 47\% indicated that it is determined on a case-by-case.

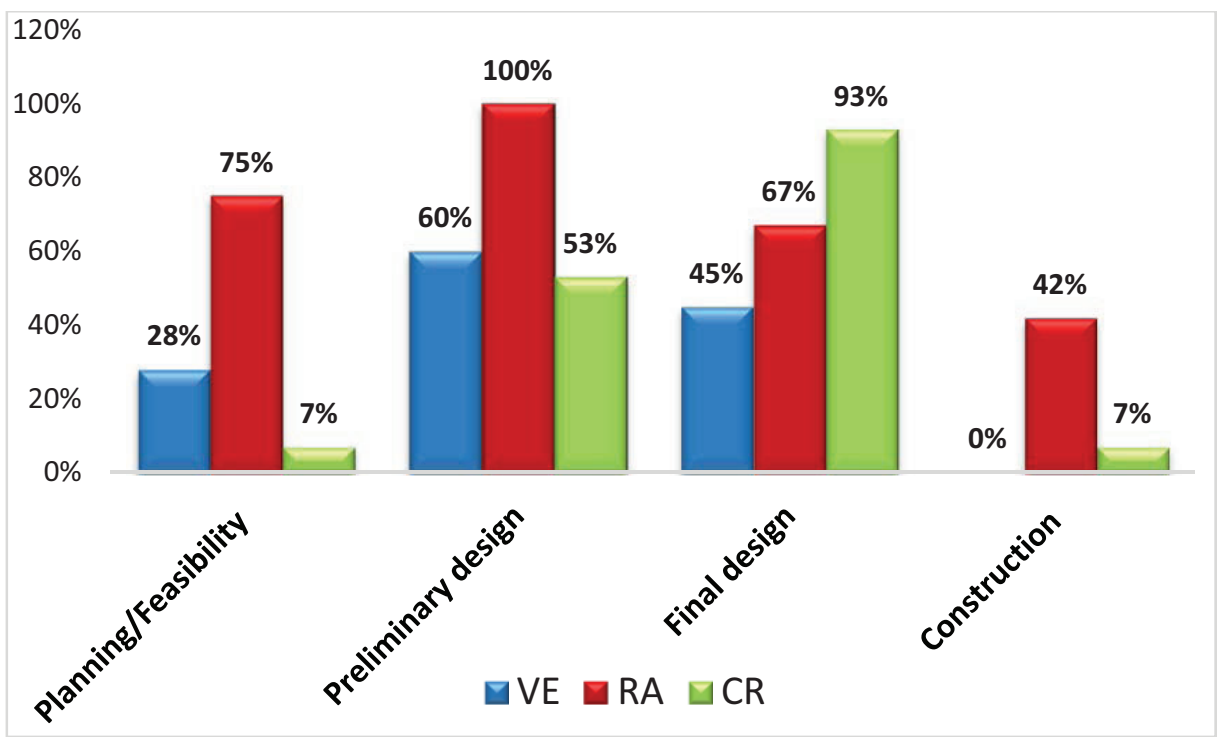

Figure (5) Timing of conducting each program

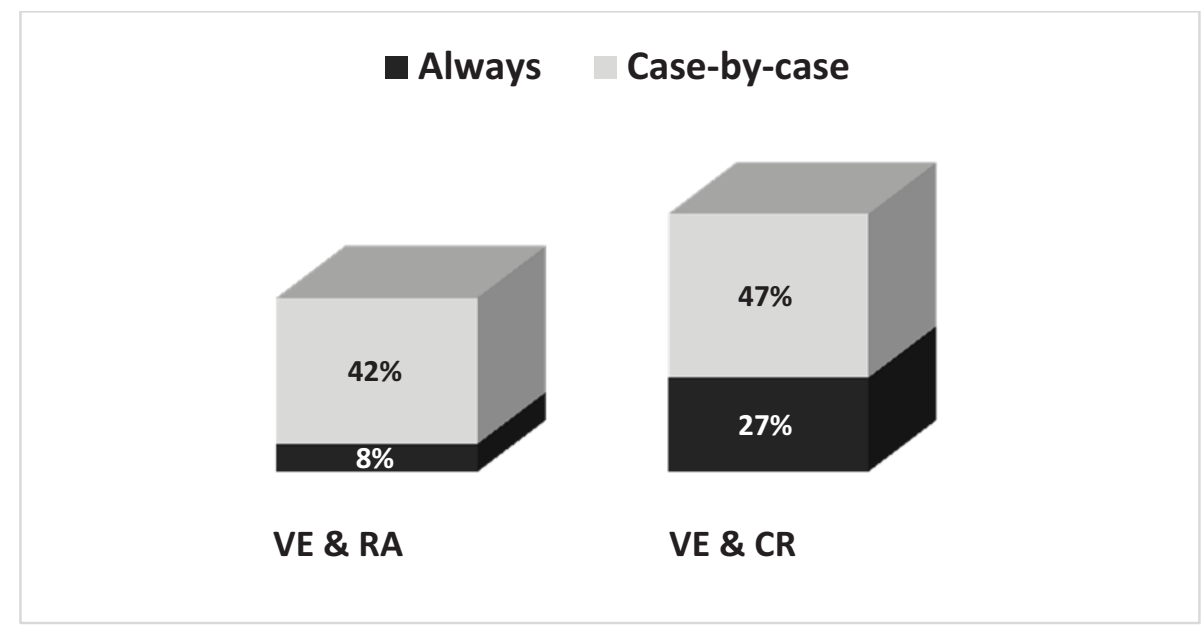

Figure (6) Integration of VE with RA and CR initiatives 


\section{G. Project delivery methods:}

The respondents were asked if they have conducted VE, $\mathrm{RA}$, or $\mathrm{CR}$ on projects in their organizations using project delivery methods, if yes they asked which of the project delivery methods have been used by their organization. Most agencies have experience with Design-Build (DB) delivery method. $90 \%$ respondents indicated that they are using design-build as a key method for transportation projects delivery. One third (about 33\%) have experience with Construction Manager / General Contractor (CMGC). The Public-Private Partnerships (PPP) was indicated by $19 \%$ respondents, $10 \%$ of them referred to Design-Build-OperateMaintain (DBOM). The last method (Design-Build-Finance-
Operate-Maintain, DBFOM) was indicated by $5 \%$ respondents (Figure 7).

The survey results in Figure 8 below shows that $100 \%$ of respondents indicated that Risk Analysis was conducted with Design-Bid-Build (DBB), 92\% was Design-Build (DB), 15\% was Early Contractor Involvement for DBB projects, 54\% was Construction Manager/General Contractor (CM/GM), and $31 \%$ was Public-Private Partnerships (PPP). Respondents who conduct Constructability Review survey indicated that Design-Bid-Build (DBB), Design-Build (DB), Early Contractor Involvement for DBB projects, Construction Manager/General Contractor (CM/GM), and Public-Private Partnerships (PPP) were 89\%, 83\%, 3\%, 10\%, and 4\% respectively.

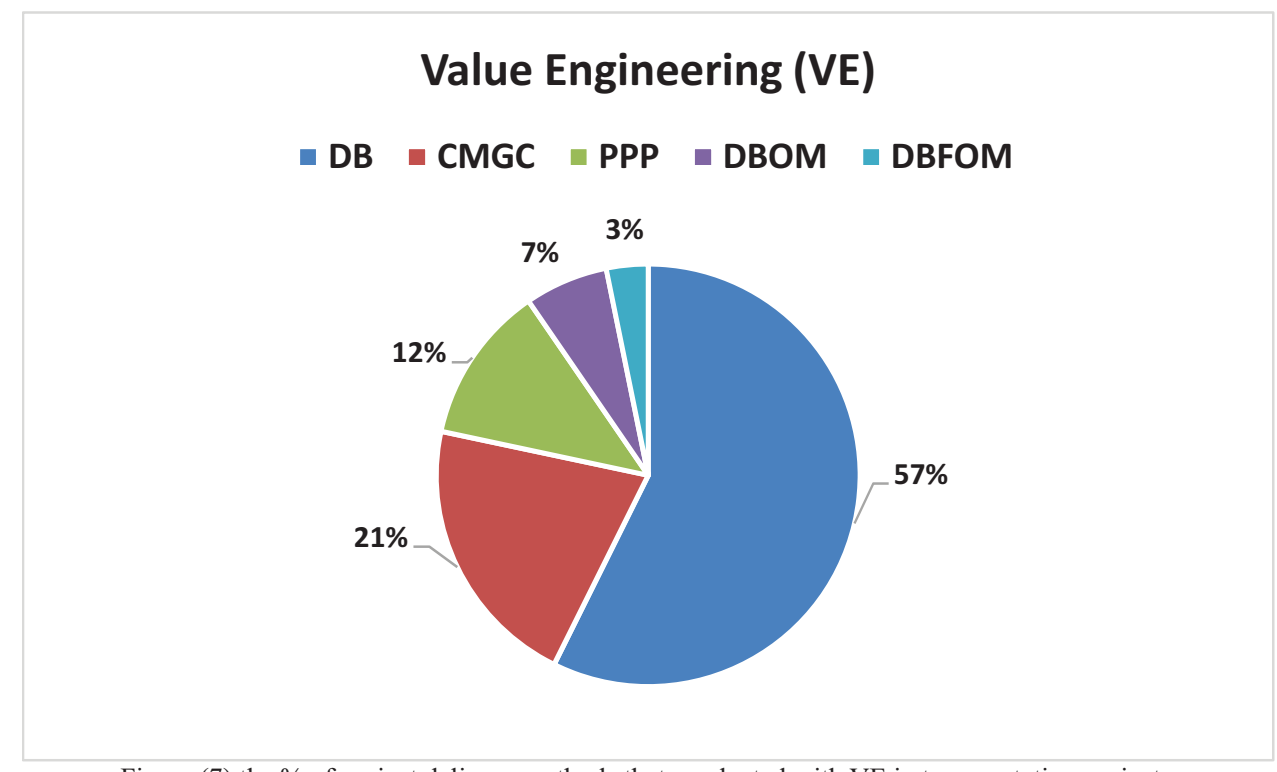

Figure (7) the $\%$ of project delivery methods that conducted with VE in transportation projects.

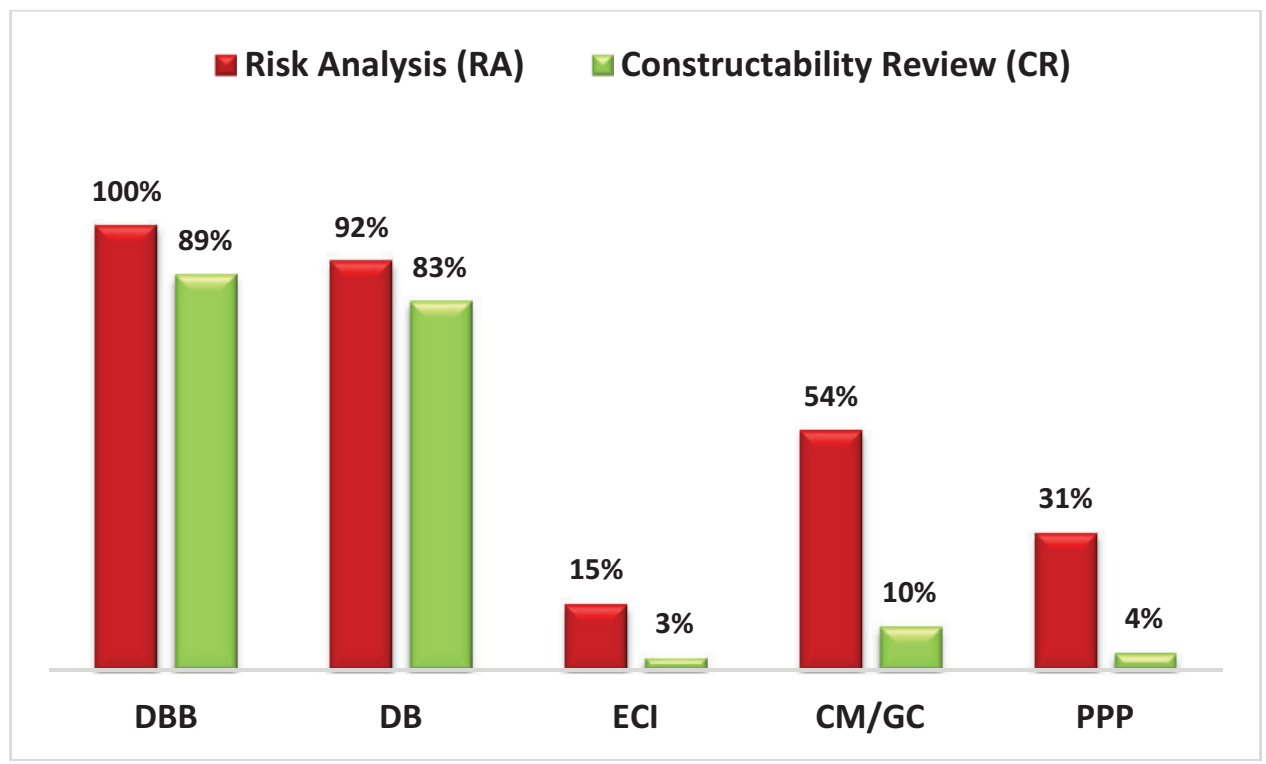

Figure (8) the \% of project delivery methods that conducted with each RA and CR in transportation projects. 


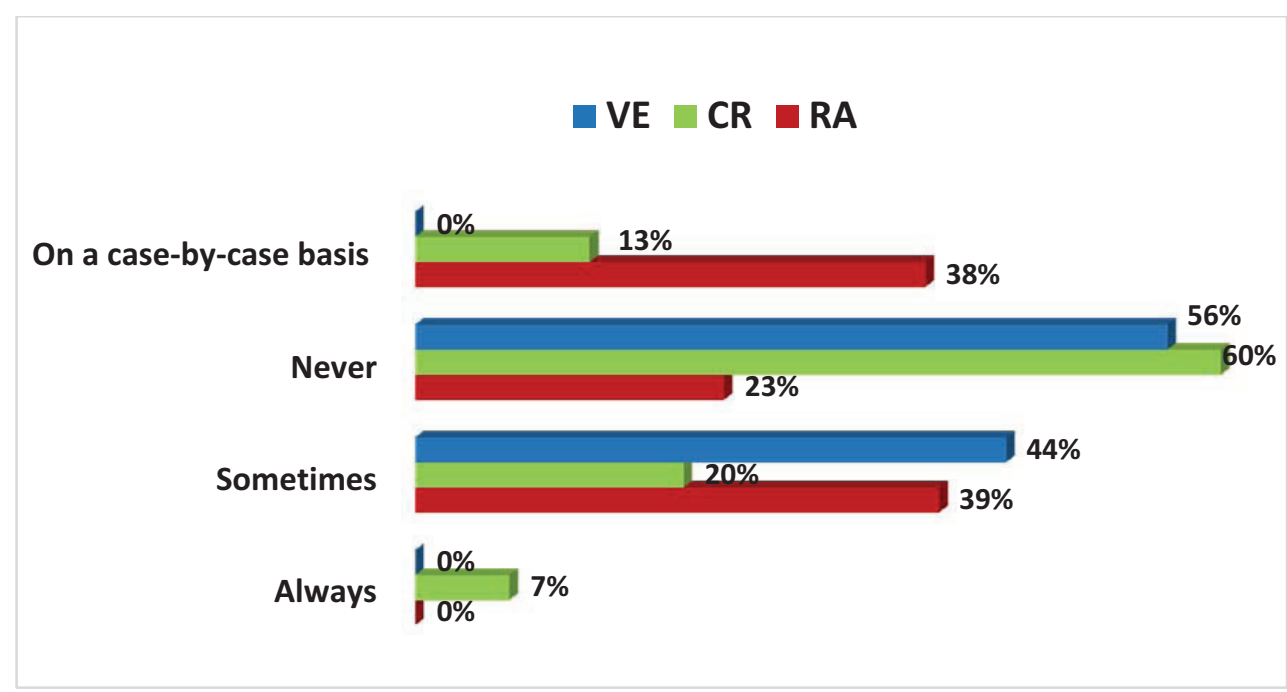

Figure (9) the \% of training conducted with the project delivery

\section{H. Training:}

The majority of respondents (about 56\%) indicated that they do not regularly provide Value Engineering training (inhouse or external). In Risk Analysis, the responding transportation agencies who conduct RA indicated that no Risk Analysis training was provided within their agencies. Others indicated they sometime provide training, never provide training, or provide training on a case-by-case basis (39\%, 23\%, and 38\% respectively). Respondents who conduct Constructability Review indicated that $7 \%$ they always provide training, $20 \%$ they sometimes do, $60 \%$ they never do, and $13 \%$ they provide training on a case-by-case basis (Figure 9).

\section{DISCUSSION}

\section{A. Value Engineering}

Value Engineering and Value Analysis is defined as an organized effort using multi-discipline teams that seek to improve project value through the analysis of functions by meeting or improving upon performance while reducing the total cost of ownership. VE seeks to find different ways to accomplish key project functions that cost less, improve performance, reduce schedule and minimize risk. It is often confused with cost reduction exercises, but is fundamentally different in theory and application.

The survey shows most agencies have a VE policy. In some state department of transportation (DOTs) Value Engineering studies are guided by a specific process based largely on American Association of State Highway and Transportation Officials (AASHTO's) guidelines for Value Engineering. [19] It is possible for Department policy to be changed when a new method is introduced through a Value Engineering study. For example, an accepted recommendation that suggests the use of a proprietary retaining wall system in lieu of a cast-in-place retaining wall would require a change in policy if the DOT has an existing policy in place that prohibits the use of proprietary retaining walls.

As shown in the survey results VE programs are mostly applied with the design function. The majority of respondents indicated that they perform Value Engineering studies during preliminary design. About half of them said that Value Engineering studies are being conducted during final engineering and some said during project planning or feasibility stage. NCHRP SYNTHESIS 352 [20] stated that the $\$ 25$ million cost threshold trigger for federal-aid projects serves as both motivation and as a limitation for some state transportation agencies (STAs). Some modest-size transportation agencies with projects falling below the $\$ 25$ million threshold rarely do Value Engineering, whereas some larger transportation agencies rarely consider Value Engineering programs on state-funded or lower-cost federalaid projects. So, the current policy for National Highway System (NHS) projects requires Value Engineering studies for each project located on where the estimated total project cost is $\$ 50$ million or more that utilizes Federal-aid highway or transit funding. While $\$ 40$ million or more that utilizes Federal-aid highway funding for each bridge project located on the NHS. The estimated total cost for purposes of the thresholds identified by the NHS and shows in the survey, is based on the best estimate of the cost to construct the project. The survey results verify the above statement and it was noticed that the majority of Value Engineering Programs have adapted the more recent, higher federal dollar value thresholds.

Value Engineering (VE) is typically performed as an isolated activity within the project delivery process. Most respondents' refer to the lack of formal feedback and lessons learned that are captured and shared during the project delivery process. This issue might be improved if the Value Engineering program integrated into the project delivery process rather than being thought of as a standalone activity. 
Value Engineering (VE) studies may be performed either in-house by an ad hoc or permanent Value Engineering team or may be performed through contracts with engineering firms experienced in Value Engineering [21]. The respondents indicated an even split between consultant-led and in-house Value Engineering studies and the use of internal vs. external technical team members.

The basic Value Engineering (VE) analysis is being executed coordinating with risk assessment workshops such as Cost Risk Assessment (CRA) or Cost Estimate Validation Process (CEVP). Value Engineering (VE) analysis should be closely coordinated with other project development activities as well as with risk assessment workshops such as CRA or CEVP [22]. The survey indicated that some agencies are using innovative VE techniques, primarily through the incorporation of some form of risk analysis and/or the use of value measurement systems. Clearly, exploring ways to incorporate these more sophisticated methods into VE studies should be further explored. Project Development Manual, Appendix 9 [23] stressed that the Department offers a minimum of one VE training course every two years. Training is necessary to maintain effective VE programs and the corporate enthusiasm to allocate resources to VE. However, training initiatives are typically influenced more by the overall funding of transportation programs [24]. Training is recommended for anyone associated with transportation projects [25]. However, the majority of respondents in the survey emphasized that they do not regularly provide Value Engineering training.

\section{B. Risk Analysis/Management}

Risk Management is comprised of several key steps including Risk Planning, Risk Identification, Risk Analysis, Risk Response Planning and Risk Monitoring and Control. Risk Workshops are conducted using multidiscipline teams to identify project related threats and opportunities; assess their probabilities and impacts to cost and schedule; and identify actions to appropriately manage risks.

The majority of respondents indicated that they have policy for applying the risk analysis or risk management in transportation projects. The risk analysis/management process is applied for effective management of project risks during entire project life cycle (from problem screening through the completion of construction) [26]. The same survey indicated that use of RA/RM techniques was more prevalent than CR in support of project delivery. However, other results indicated that use of RA tools and techniques are becoming more common in the delivery of transportation projects.

Most agencies do not have an established dollar threshold for performing RA and commonly include it as part of project delivery activities. RA efforts are mostly conducted using a combination of internal and external consultant staff. Some respondents' comments referred to the justification of using the RA by internal or external staff or both of them together that RA is dependent on the competencies in term of personal capabilities. The majority of states are developing internal personnel, but some of them do not have experienced internal staff and are using external consultants. The need for RA is most commonly determined on a case-by-case basis, the survey results indicated that $42 \%$ of respondents said RA is used in combined with VE efforts in the transportation projects. Most of them indicated a single RA effort is the most common application of RA on any given project, with a smaller percentage performing continuous risk management activities throughout the project delivery lifecycle. Most agencies do not spend time on RA/RM efforts. In terms of integrating effective practices and innovative methods for project delivery, the integration of RA/RM and VE has been proven; however, CR has generally not been integrated with RA/RM efforts. [27] In the California Department of Transportation (Caltrans), project risk management process is intended to be applied during the entire project life cycle from project inception to completion of construction. Caltrans emphasize the scalable risk management approach (i.e. Level 1, 2, and 3). Therefore, the time for some particular risk management tools are different. Generally, simpler projects may use simple qualitative analysis, whereas larger more complex projects may use more robust/quantitative analysis techniques such as simulation. The respondents considered $\mathrm{RA} / \mathrm{RM}$ as an ongoing and integrated component of project management and needs to be performed through the project life cycle. No specific project RA training is using within transportation agencies. The majority of the responding transportation agencies indicated that no RA training was provided within their agencies.

\section{Constructability Review}

Constructability Reviews typically focus on managing construction related risks at two levels. The first is identifying and mitigating issues related to the constructability and biddability of projects. The second is performing a thorough review of construction bid documents (e.g., plans and specifications) to identify errors, omissions and discrepancies that could lead to quality defects and /or construction change order and claims.

As mentioned in the survey data analysis section, most of transportation organizations did not have a formal CR policy. However, those they did not have a formal CR policy they have started to establish and updated the CR policy within their organizations. Most CR policies were recently updated between 2010 and 2012. These updates covered project requirements to perform $\mathrm{CR}$ on large, complex, or issueridden projects. For example; [28] the Idaho Department of Transportation incorporates constructability review into the existing design review process as outlined in the Design Manual. For determining the level of constructability review required, projects are categorized as level one, two or three. Simple state and federal projects are considered level one. Complex projects are typically considered level two. Complex projects with new, innovative, expensive or 
complex design features may be considered level three. Project will be designated as level three at the discretion of the District.

In spite of this, $82 \%$ of respondents indicated that their DOT does not establish a dollar threshold for conducting constructability reviews for transportation projects. However, those organizations that do have a dollar threshold policy indicated that generally all projects must undergo a review. Other agencies indicated that project costs in exceedance of $\$ 500,000$ was the threshold that triggers the need for a constructability review. The North Carolina Department of Transportation uses a 5-year work plan to conduct constructability reviews on the department projects. These projects have a combined-estimate greater than $\$ 10$ million regardless of its location in the design life cycle [29]. The rate of 87 respondents is reflected that great majority of agencies conducting Constructability Review have internal staff with specific experience comparing with the very minimal training that provide to them.

Caltrans has some initiatives to integrate alternative project delivery methods on all major projects on the State Highway System that exceed the Minor A limit as defined by the California Transportation Commission. These integrations do not include other programs such as Value Engineering or Risk Analysis [30]. In this survey the respondents indicated that there are little or no specific connections or references are made between the state's CR program to other design and project review processes such as VE and RA. Finally, as noticed from the survey, most constructability reviews are conducted on the final plans, specifications and estimates (PS\&E), although a significant portion of reviews were also indicated to be conducted during preliminary design. For example; the Georgia Department of Transportation has updated their Constructability Review policy to perform CRs after Concept Report approval during the preliminary design phase, near $30 \%$ plan completion [31].

\section{CONCLUSION}

DOTs are still working to improve their projects delivery by applying value improving processes, tools, and techniques. These improvements align with identifying and adapting other innovative approaches that could be applied to improve outcomes for transportation related projects. To determine whether states have adapted any innovative project delivery process or technique, state DOT initiatives were studied through a review of past research and reports. Also, the collection of documents relevant to DOT practices that have been used as a literature review to identify and design the survey questions. Then, in-depth survey of Value Engineering (VE), Risk Analysis (RA), and Constructability Review (CR) were carried out with state DOT staff. Finally, the survey results were validated and discussed to address the main issues of these programs and the level of its conducting within the project delivery processes related to transportation construction projects. The survey results show a very clear picture regarding the practice of these project improving programs within public transportation agencies: These techniques have generally not been integrated with each other and are performed as separate efforts. However, some of the Value Engineering survey respondents' feedback was aligned with DOT reports that $15 \%$ of them either directly incorporated or immediately followed a Risk Analysis activity. The survey results further support this as $8 \%$ of survey respondents indicated that Risk Analysis was always performed in conjunction with Value Engineering. Only 27\% of respondents were indicated that Constructability Review are integrated with Value Engineering, while 31\% with Risk Analysis. Most of these conjoined activities were carried out based on policies or requirements. The most significant part was in the Constructability Review survey findings that most transportation organizations did not have a formal CR policy $(59 \%)$ than those that did have a formal policy or guidance. In terms of improving existing processes by performing these initiatives to align with the objectivity of its activities, the respondents recommended the involvement the project delivery team in this improvement or the changes. According to the survey findings, the majority of respondents indicated that they do not regularly provide VE, RA, or CR training. $56 \%$ indicated that they never provide Value Engineering training, and $60 \%$ said that they never provide Constructability Review training. For Risk Analysis, about $23 \%$ indicated they never provide Risk Analysis training while $39 \%$ were provided on case-by-case basis. The last notable point in the survey findings was the communication issue. Some respondents referred to communication as a key in implementing new innovative project delivery systems. They emphasized that many innovative delivery methods alter the process for many areas in DOTs as well as with industry partners. Identifying what will need to change, how they will change, and coordinating the details with the affected areas early in the development process will help the project move forward.

\section{ACKNOWLEDGMENTS}

The authors would like to thank the TRB and NCHRP for their support in our research endeavors. Extended thanks also go out to all the state DOTs and other local transportation organizations who participated in the survey process. Finally, we are very grateful to NCHRP 19-11 research team (PSU \& VMS) for all the help, the survey would not have been possible without their support and guidance.

\section{REFERENCES}

[1] Mendez, V., "Every Day Counts: Innovation Initiative," Federal Highway Administration, Washington, D.C., 2010, pp. 1-2.

[2] Walewski, J., G.E. Gibson, Jr., and J. Jasper, Project Delivery Methods and Contracting Approaches Available for Implementation by the Texas Department of Transportation, Report No. FHWA/TX-0-2129-1, Center for Transportation Research, Austin, Tex., 2001, 116 pp. 
[3] Understanding Project Delivery for the Design and Construction of Public Buildings, AIA Minnesota, A socitey of the American Institute Architects. content/uploads/project_delivery.pdf

[4] Anderson, S. D., and I. Damnjanovic, NCHRP Synthesis 379: Selection and Evaluation of Alternative Contracting Methods to Accelerate Project Completion, Transportation Research Board of the National Academies, Washington, D.C., 2008, 68 pp.

[5] Tran, D. and Molenaar, K. Risk-Based Project Delivery Selection Model for Highway Design and Construction." J. Constr. Eng. Manage. 2015.

[6] Terry Hays, R., Value Engineering on Design-Build Transportation Projects, Achieving Value, 2006. www.value-eng.org

[7] Value Engineering, Manual of Instruction, Utah Department of Transportation, 2015

[8] Value Engineering in the Federal-Aid Highway Program, Federal Highway Administration, U.S. Department of Transportation, 2007.

[9] Value Engineering, Federal Highway Administration, U.S. Department of Transportation, Washington, D.C. www.fhwa.dot.gov/ve/.

[10] Wilson, D.C., NCHRP Synthesis 352: Value Engineering Applications in Transportation, Transportation Research Board of the National Academies, Washington, D.C., 2005.

[11] David Ruby, Constructability Maximizing Simplicity, STRUCTURE magazine, June 2006. Www.structuremag.org/wpcontent/uploads/2014/09/SF-Constructability-Part-I-June-061.pdf

[12] Constructability Review Guidelines, Idaho Transportation Department (ITD), 2011.

[13] Constructability Guide Book, Indiana Department of Transportation (INDOT), www.in.gov/indot/files/ConstructabilityReviewProcess.pdf

[14] Construction Manager/General Contractor (CMGC) Manual, Colorado Department of Transportation (CDOT), 2014.

[15] Risk Management Guideline, New Jersey Department of Transportation $\quad 2015$. www.state.nj.us/transportation/capital/pd/documents/RiskManagement Guideline.pdf

[16] Guide for Managing NEPA-Related and Other Risks in Project Delivery, Volume 1, Washington, DC, 2011
[17] Alternative Technical Concepts for Contract Delivery Methods, NCHRP SYNTHESIS 455, 2014. www.TRB.org

[18] Guide for managing NEPA-Related and Other Risks in Project Delivery, NCHRP, Volume 1, 2011.http://onlinepubs.trb.org/onlinepubs/nchrp/nchrp_W183v1.pdf

[19] Value Engineering in Design, Project Development Manual, Appendix 9, New York State Department of Transportation (NYSDOT), 2015

[20] Value Engineering Applications in Transportation, NCHRP SYNTHESIS 352, A Synthesis of Highway Practice, Transportation Research Board, 2005

[21] Value Engineering, Chapter 2-E, Federal Lands Highway Manual, Federal Lands Highway, 2012

[22] Value Engineering, Chapter 310, Design Manual, Washington State Department of Transportation (WSDOT), 2013

[23] Value Engineering in Design, Project Development Manual, Appendix 9, New York State Department of Transportation (NYSDOT), 2015

[24] Value Engineering Applications in Transportation, a Synthesis of Highway Practice, NCHRP - Synthesis 352, 2005

[25] Value Engineering Program for Transportation Projects Policy, Oregon Department of Transportation (ODOT), 2014

[26] Risk Management Guideline, New Jersey Department of Transportation, 2015. www.state.nj.us/transportation/capital/pd/documents/RiskManagement Guideline.pdf

[27] Project Risk Management Handbook, California DOT (Caltrans), 2012. www.dot.ca.gov/hq/projmgmt/documents/prmhb/PRM_Handbook.pdf

[28] Constructability Review Guidelines, Idaho Department of Transportation, 2011. http://www.idaho.gov/manuals/

[29] Value Management Program Policy and Guidelines, North Carolina Department of Transportation, 2015. https://connect.ncdot.gov/resources/Products/Documents/VMP\%20Gui delines $\% 205 \% 200 \% 20$ Value $\% 20$ Management.pdf

[30] Constructability Reviews, California Department of Transportation, 2010. http://www.dot.ca.gov/hq/oppd/design/PD-05.pdf

[31] Plan Development Process, Georgia Department of Transportation, 2015.

http://www.dot.ga.gov/PartnerSmart/DesignManuals/PDP/PDP.pdf

\section{$\underline{\text { Appendix }}$}

\section{SURVEY QUESTIONS}

\section{OVERVIEW QUESTIONS}

- What agency/organization do you currently represent? (User open ended response

- What is your position in the organization? (User open ended response

- Would you be open to brief follow-up discussion?

$\circ$ Yes

$\circ$ No

- If yes, please provide your contact information. (User open ended response

VALUE ENGINEERING QUESTIONS:

- Under what division/office/ bureau does Value Engineering reside within your organization:
○ Design
- Construction
- Other (User open ended response

- Does your organization have a formal Value Engineering policy?
$\circ$ Yes
- No
- If yes, when was the policy last updated? (User open ended response

- What is the (\$) dollar threshold for performing VE on transportation projects in your organization?

Less than $\$ 10$ million

- \$10 -\$25 million 


\section{Proceedings of PICMET '16: Technology Management for Social Innovation}

- \$25-\$40 million

- \$40- \$50 million

- Other? (User open ended response

- What are other parameters for selecting projects to perform VE studies on transportation projects in your organization (select all that apply)?

- Phasing Complexity

- Staging Complexity

○ Right-of-Way Issues

- Environmental Impacts

- Utilities Impacts

- Technical challenges

- External agency/stakeholder involvement

- Building consensus with multiple stakeholders

- Please identify when it is most common to perform VE within your organization (select all that apply):

$\circ \quad$ Planning and Programming (Feasibility Studies)

$\circ$ Environmental Studies/Preliminary Design ( $<30 \%$ level of development)

- Final Design / Plans, Specifications and Estimates ( $>30 \%$ level of development)

- Select the most common method in which VE studies are conducted in terms of leading the effort:

$\circ$ Internally facilitated

- Externally facilitated (i.e., consultant)

$\circ$ Both internally and externally facilitated

- Select the most common composition of VE teams for studies conducted for your organization:

$\circ$ Internal team members

- External team members (i.e., consultant)

$\circ$ Both internal and external team members

- Select the best answer to the following statements to understand how VE is perceived within your organization:

$\circ$ VE is a performance and/or quality improvement method.

- Strongly Agree

- Agree

- Unsure

- Disagree

- Strongly Disagree

- VE is a cost management tool.

- Strongly Agree

- Agree

- Unsure

- Disagree

- Strongly Disagree

- VE is a schedule management tool.

- Strongly Agree

- Agree

- Unsure

- Disagree

- Strongly Disagree

$\circ \quad$ VE is a risk management tool.

- Strongly Agree

- Agree

- Unsure

- Disagree

- Strongly Disagree

- Is there any type of feedback loop (i.e. lessons learned) in your organization between construction field experiences back to VE studies?

$\circ$ If so, please describe (user open ended response)

- Is there any type of feedback loop (or lessons learned) in your organization between VE study findings to preconstruction project delivery phases? 


\section{Proceedings of PICMET '16: Technology Management for Social Innovation}

- If so, please describe (user open ended response)

- Has your organization conducted VE studies on projects using any of the following project delivery methods? (check all that apply)

$\circ$ Design-Build

- Construction Manager General Contractor (CMGC)

- Public Private Partnerships (P3)

○ Design Build Operate Maintain (DBOM)

$\circ \quad$ Design Build Finance Operate Maintain (DBFOM)

- Does your organization do anything unique or especially effective with respect to its application of Value Engineering that you feel would like to share with other public transportation agencies?

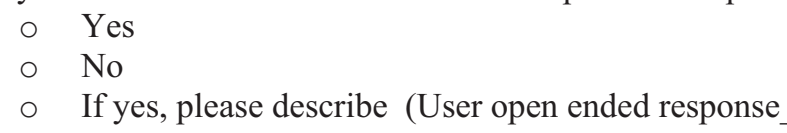

- Does your organization regularly provide Value Engineering training for project delivery personnel?

○ Yes

○ No

- If yes, please describe (User open ended response

- Within your organization is there an individual that manages Project Delivery?

○ Yes

- No

- If yes, please provide contact information (Name, Title/Position, Email, Telephone) (User open ended response

- Within your organization is there an individual that manages (Project) Risk Analysis?

$\circ$ Yes

- No

- If yes, please provide contact information (Name, Title/Position, Email, Telephone) (User open ended response

- Within your organization is there an individual that manages Constructability Reviews?

○ Yes

- No

$\circ$ If yes, please provide contact information (Name, Title/Position, Email, Telephone) (User open ended response

\section{RISK ANALYSIS QUESTIONS:}

- Under what division/office/ bureau does Risk Management reside within your organization, i.e. Division of Design, Division of Project Management, Division of Construction?

- Does your organization have a formal Risk Analysis policy?

$\circ \quad$ If so, when was the policy last updated?

- Does your organization have specific individual(s) delegated to manage your Risk Analysis efforts?

- Does your organization have an established dollar threshold for performing a Risk Analysis?

- If so, what are the parameters for performing Risk Analysis on transportation projects in your organization?

- Less than $\$ 25$ million

- $\$ 25-\$ 50$ million

- $\$ 50+$ million

- Other?

- What are other parameters for selecting projects to perform a Risk Analysis study on transportation projects in your organization (select all that apply)?

○ Phasing Complexity

$\circ$ Staging Complexity

- Right-of-Way / Utilities Impacts

- Number of structures in project area

$\circ$ Other agency/stakeholder involvement

- Environmental Impacts

- Which of the following statements best characterize how project managers in your organization perceive Risk Analysis? 


\section{Proceedings of PICMET '16: Technology Management for Social Innovation}

- Risk Analysis is universally recognized amongst project managers as a value added project delivery activity.

- Most project managers see the benefits of Risk Analysis and believe it has a positive impact on project delivery.

- Opinions about Risk Analysis are divided amongst project managers as to the positives and negatives.

- Most project managers do not see the benefits of Risk Analysis and believe it has a negative impact on project delivery.

- Risk Analysis is an activity to be avoided by project managers and it is generally seen as a "check the box" requirement.

- What phases of project development/delivery is Risk Analysis performed within your organization (select all that apply):

$\circ \quad$ Planning and Programming (Feasibility Studies)

$\circ$ Environmental Studies/Preliminary Design $(<30 \%$ level of development)

$\circ \quad$ Final Design / Plans, Specifications and Estimates ( $>30 \%$ level of development)

$\circ$ Construction

- At what phase of project development/delivery Risk Analysis is most commonly performed within your organization:

$\circ$ Planning and Programming (Feasibility Studies)

- Environmental Studies/Preliminary Design ( $<30 \%$ level of development)

$\circ \quad$ Final Design / Plans, Specifications and Estimates ( $>30 \%$ level of development)

- Construction

- When conducting Risk Analysis studies, what are the team members commonly comprised of (select all that apply):

$\circ$ Design

- Structures

- Geotechnical

- Hydraulics

○ Environmental

- Traffic Operations

- Traffic Safety

$\circ \quad$ Landscaping

○ Maintenance

- Construction

- Project Management / Oversight

- Other

- Select the most common method in which Risk Analysis studies are conducted in terms of leading the effort:

$\circ$ Internally facilitated

$\circ \quad$ Externally facilitated (i.e., consultant)

$\circ$ Both internally and externally facilitated

- Select the most common composition of Risk Analysis teams for studies conducted for your organization:

- Internal team members

- External team members (i.e., consultant)

$\circ \quad$ Both internal and external team members

- Are Risk Analysis modeling efforts conducted outside of your organization's Risk Analysis workshop?

- Which types of Risk Analysis does your organization most commonly conduct:

$\circ$ Qualitative

- Semi-quantitative (i.e., calculation of expected probability and impacts)

- Quantitative (i.e., calculation of expected probability and impacts in combination with Monte Carlo simulation)

- Quantitative Integrated Cost-Schedule (i.e., calculation of expected probability and impacts in combination with Monte Carlo simulation that marries planned project cost expenditures to project schedules)

- Does your organization have any project criteria that requires Quantitative Risk Analysis in lieu of less sophisticated Risk Analyses (i.e., Qualitative and Semi-Quantitative)?

$\circ$ If so, please describe (user open ended input)

- Do your organization's Risk Analysis studies include Risk Management activities for Risk Response Planning and Risk Monitor and Control?

○ If so, how much time is applied when a Risk Analysis is conducted in performing Risk Management activities (i.e., Risk Response Planning and Risk Monitor and Control Activities)? 


\section{Proceedings of PICMET '16: Technology Management for Social Innovation}

- Less than $10 \%$ of the time expended

- $10-30 \%$ of the time expended

- $30-60 \%$ of the time expended

- Does your organization have a formal Risk Management clause that is included in all construction bid documents (i.e., requirement for maintenance of risk registers)?

$\circ \quad$ If so, whose responsibility is it?

- Construction contractor

- Internal staff

- External staff (i.e., consultant)

- Other

- Is there any type of feedback loop (or lessons learned) between construction field experiences that informs Risk Analysis studies in your organization?

- If so, please describe (user open ended response)

- Do you perform Risk Analysis in combination with VE studies?

- Do you perform in Risk Analysis combination with constructability review studies?

- Have you used other types of project management/delivery tools and techniques in combination with Risk Analysis studies?

- If so, please describe (user open ended input)

- Does your organization do anything unique or especially effective with respect to its application of Risk Analysis that you feel would like to share with other public transportation agencies?

- Does your organization regularly provide Risk Analysis training for project delivery personnel?

\section{CONSTRUCTABILITY REVIEW QUESTIONS:}

- Under what division/office/ bureau do Constructability Reviews reside within your organization, i.e. Division of Design, Division of Project Management, Division of Construction?

- Does your organization have an official Constructability Review policy?

- If so, when was the policy last updated?

- Does your organization have specific individual(s) delegated to manage your Constructability Review efforts?

- Does your organization have a separate Constructability Review unit?

- Does your organization have an established dollar threshold for performing a Constructability Review?

- If so, what are the parameters for performing Constructability Reviews on transportation projects in your organization?

- Less than $\$ 25$ million

- $\$ 25-\$ 50$ million

- $\$ 50+$ million

- Other?

- What are other parameters for selecting projects to perform a Constructability Review study on transportation projects in your organization (select all that apply)?

- Phasing Complexity

- Staging Complexity

○ Right-of-Way Issues

- Utilities Impacts

- Other agency/stakeholder involvement

- Environmental Impacts

- New/Advanced Technical Challenges

- Developing consensus decisions involving multiple stakeholders

- Which of the following statements best characterize how project managers in your organization perceive Constructability Reviews?

- Constructability Reviews are universally recognized amongst project managers a value added project delivery activity.

- Most project managers see the benefits of Constructability Reviews and believe it has a positive impact on project delivery.

- Opinions about Constructability Reviews are divided amongst project managers as to the positives and negatives. 


\section{Proceedings of PICMET '16: Technology Management for Social Innovation}

$\circ$ Most project managers do not see the benefits of Constructability Reviews and believe it has a negative impact on project delivery.

- Constructability Reviews are an activity to be avoided by project managers and it is generally seen as a "check the box" requirement.

- What phases of project development/delivery are Constructability Reviews performed within your organization (select all that apply):

$\circ \quad$ Planning and Programming (Feasibility Studies)

$\circ$ Environmental Studies/Preliminary Design $(<30 \%$ level of development)

- Final Design / Plans, Specifications and Estimates ( $>30 \%$ level of development)

$\circ$ Construction

- At what phase of project development/delivery are Constructability Reviews most commonly performed within your organization:

○ Planning and Programming (Feasibility Studies)

- Environmental Studies/Preliminary Design $(<30 \%$ level of development)

- Final Design / Plans, Specifications and Estimates ( $>30 \%$ level of development)

$\circ$ Construction

- Select the most common method in which Constructability Review studies are conducted in terms of leading the effort:

$\circ$ Internally facilitated

- Externally facilitated (i.e., consultant)

$\circ$ Both internally and externally facilitated

- Select the most common composition of Constructability Review teams for studies conducted for your organization:

$\circ$ Internal team members

- External team members (i.e., consultant)

$\circ$ Both internal and external team members

- Is there a prescriptive check-list of participants for reviews during your organization's constructability reviews?

$\circ$ Do your check-lists identify specific individual disciplines for participation?

If so, please select all that apply:

- Design

- Structures

- Geotechnical

- Hydraulics

- Environmental

- Traffic Operations

- Traffic Safety

- Landscaping

- Maintenance

- Construction

- Project Management / Oversight

- Other

- When performing a constructability review, what are the key elements of focus commonly applied (select all that apply):

○ Plans

- Specifications

- Estimates / Bid Items

- Construction Contracting Language

- Is there any type of feedback loop (or lessons learned) in your organization between construction field experiences back to constructability review studies?

$\circ \quad$ If so, please describe (user open ended response)

- Do you perform constructability reviews in combination with VE studies?

- Do you perform constructability reviews in combination with Risk Analysis studies?

- Have you used other types of project management/delivery tools and techniques in combination with your Constructability Review studies?

$\circ \quad$ If so, please describe (user open ended input) 
- Does your organization do anything unique or especially effective with respect to its application of Constructability Review that you feel would like to share with other public transportation agencies?

- Does your organization regularly provide Constructability Review training for project delivery personnel? 